\title{
Leibniz, Lefebvre and the spatial turn in law
}

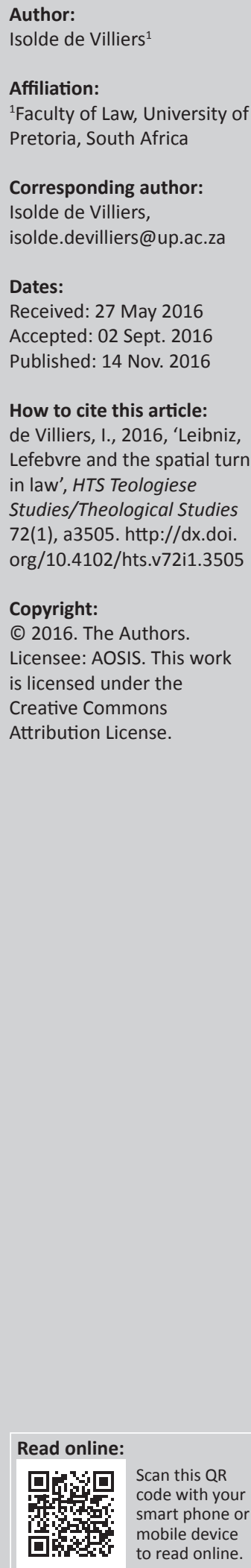

This contribution takes as its point of departure the spatial turn in law and the notion of spatial justice. It traces the term 'spatial justice' as introduced through the Spatial Planning and Land Use Management Act and it looks at the underlying view of space that has influenced the spatial turn in law. It furthermore investigates the ways in which the spatial turn in law has been influenced by the thinking of Henri Lefebvre, who relies on a Leibnizian conception of space. Lastly the link between Leibniz and legal positivism is considered in order to reach the final conclusion in the form of a caution against merely adding the language of spatial justice to an approach to space that remains caught up in abstract space. This will only further entrench existing fault lines in society. For this conclusion the work of Roger Berkowitz is central. Berkowitz argues convincingly that the work of Leibniz was central in the development of legal positivism, despite Leibniz in general being considered as a natural law thinker. The same applies to spatial justice theory, where the work of Leibniz is central: it may present the possibilities of another law - the law as it ought to be. The law conceptualised as 'ought' instead of 'is' would promote reconciliation. Alternatively, spatial justice can simply present the law as it 'is' and reconfirm and deepen the chasms in our world.

We can say also that God, the Architect, satisfies in all respects God the Law Giver, that therefore sins will bring their own penalty with them through the order of nature, and because of the very structure of things, mechanical though it is. And in the same way the good actions will attain their rewards in mechanical way through their relation to bodies ... (Leibniz 1714:89)

\section{Introduction}

In this contribution I consider whether the discourse on spatial justice within the field of law could contribute to reconciliation, by focusing on relational space and its role in spatial justice literature in the context of law. I am particularly interested in how the theological justification for Leibniz's alternative to abstract space, and accordingly relational space, has influenced the spatial turn in law. If the focus of reconciliation is the mending of relationships, then a relational approach to space and a relationally informed spatial turn in law is required. In this regard I argue that if the spatial turn in law merely entails the incorporation of spatial metaphors or geographical references it risks maintaining a view of space as abstract. Instead, law should open to the destabilising uncertainty of space as relational. Viewing space as relational acknowledges that space produces relationships. The extent to which courts often disregard the law's role in producing space, and by extension the production of relationships, serve as a point of departure to call for a greater awareness in the ways in which law produces and reproduces spatial relations and by extension facilitates or hinders reconciliation.

One of the key influences in the spatial turn in law is the work of French philosopher Henri Lefebvre. Chris Butler explains that Lefebvre relies on a philosophical alternative to absolute space (2012:39-40). This alternative is based on Leibniz's view of space, which is different from that of Descartes and Newton. For Descartes, space was grid-like and corresponded with the mathematical principle of the Archimedean point, on which his entire philosophy was based. This principle also relates to the first Cartesian principle of cogito ergo sum and, just like Archimedes' single strong point from which the Earth can be moved, the perspective of an individual can somehow be generalised as a broader view of the world (Tally 2013:27). Descartes held that space cannot be separated from bodies in space and therefore rejected a view of space as a vacuum or vessel within which bodies are held. This view of space as a substance in itself is congruent with a Euclidean notion of space, but departs from the classical view of space as a 'plenum that was full of matter'. This view was held for instance by atomist Lucretius around the first century BCE. The idea of space as a vacuum, however, was embraced by Newton, who disagreed with Descartes in viewing space as 'absolute, independent, infinite, three-dimensional, eternally fixed' as a container

Note: This article is part of the Special Collection titled 'Spatial Justice and Reconciliation', sub-edited by Stephan de Beer, of the Department of Practical Theology and the Centre for Contextual Ministry, University of Pretoria. 
(Tally 2013:28). The objection of Leibniz (as typified by Tally) against the Newtonian view of space was founded in theology. This, Leibniz pointed out, was because Newton's notion of space leads to a situation where space would have existed before God's creation and this, for Leibniz, was untenable. The theory of Leibniz has been used to conceptualise a relational theory of space and time, which played an important role in the work of critical human geographers, such as Doreen Massey $(1994,2005)$.

Firstly I look at the provisions in the Spatial Planning and Land Use Management Act 16 of 2013 (SPLUMA) in order to sketch the possibilities of spatial justice, redress and reconciliation through a process of legal enactment in South Africa. The possibilities presented by the act are not guaranteed, however, especially if an absolute view of space still underpins the very legal system that attempts to bring redress and reconciliation through spatial justice. In unpacking this claim, I look at the work of Lefebvre, who relied on Leibniz to call for space as indiscernible; space not as a vacuum, but as being produced by bodies in space. From this appreciation of space I look at the broader spatial turn in law and then turn to the possibility of spatial justice (like the ideas of Leibniz) to be employed in the project of legal positivism. This will ultimately lead to a denial of the relational character of space, and reconciliation and redress through legal processes, rooted in a view of absolute space, will (again) fail, rendering the promises of the SPLUMA empty. I rely mainly on the work of Roger Berkowitz to critically consider Leibniz's contribution to the spatial turn in law and the possibility of spatial justice to be another of science's gifts to law. Specifically, spatial justice will only strengthen the current unequal and unjust apparatus of law unless it is radically opened up to the uncertainties presented by relational space.

\section{Spatial planning and Land Use Management Act}

The term 'spatial justice' formally made its appearance in South African legislation in the SPLUMA of 2013. The preamble to the act sets out its aims. Importantly, it envisions spatial planning that is 'inclusive, developmental, equitable and efficient'. The act also aims to ensure that different levels of government address regulatory and special imbalances. This, the preamble states, is in addition to encouraging greater 'consistency and uniformity' in decision-making and other procedures undertaken by various forms of authority that are responsible for decisions on the utilisation of land.

Spatial justice becomes a formal requirement in all documentation drafted by different spheres of government. Section 4 of the act determines that development principles, norms and standards must guide spatial planning, land use management and land development. The notion of development principles is expanded in section 7 , with spatial justice as the first principle. Spatial justice is unpacked to cover redress of 'spatial and other imbalances' through better access to and use of land (section (7)(a)(i) of SPLUMA). No further content is given as to what these imbalances entail, how the past has impacted on this nor the way in which space reproduces unequal social relationships. The second paragraph of section (7)(a) moves on to policy requirements:

(7)(a)(ii) spatial development frameworks and policies at all spheres of government must address the inclusion of persons and areas that were previously excluded, with an emphasis on informal settlements, former homeland areas and areas characterised by widespread poverty and deprivation ... (section (7)(a)(ii) of SPLUMA)

The section also addresses spatial planning mechanisms, which include land use plans, and requires that it must include mechanisms for putting into place processes to provide disadvantaged communities with access to land, as a process of redress. The Khulumani victim support group has consistently called for redress in light of the lack of reconciliation due to the limitations of the Truth and Reconciliation Commission (TRC) and the failure of the government of South Africa to deliver what was promised, namely reparations for victims of gross human rights abuses under apartheid (Kesselring 2016; Norval 2009). Aletta Norval, drawing on a post-structuralist approach to discourse analysis, with specific reference to Laclau and Rancière, traces the difference between the notions of reconciliation and redress and argues that redress can introduce new inroads into political imagination and action. Khulumani coined the phrase ' $[n]$ o reconciliation without redress'.

The term 'reconciliation' is not used in the SPLUMA, but redress is a specific aim. Section 7, under the principle of spatial justice, also requires all management systems for land use to be flexible and relevant to disadvantaged areas, with specific mention of informal settlements and former homeland areas. The subsection also requires that all areas of a municipality should be covered by management systems for that area:

(v) land development procedures must include provisions that accommodate access to secure tenure and the incremental upgrading of informal areas; and

(vi) a Municipal Planning Tribunal considering an application before it, may not be impeded or restricted in the exercise of its discretion solely on the ground that the value of land or property is affected by the outcome of the application ... (SPLUMA [7][a][iv])

The other developmental principles include spatial sustainability, spatial efficiency, spatial resilience and good administration (section 7(b) through 7(c) of SPLUMA). At face value it seems as if the act has a deep form of reconciliation in mind (even though it is not pertinently articulated in SPLUMA). The question of the degree to which the act will achieve such reconciliation through redress will, to a large degree, depend on the underlying understanding of spatial justice, and therefore how space is conceptualised. If spatial justice becomes yet another formal requirement for municipal policies relating to land and land use, then space returns to its abstract conception and loses the relational qualities first 
introduced by Leibniz and taken up by the spatial turn in law through the work of Lefebvre. I now turn to a brief overview of the spatial turn in law more generally, before embarking on a discussion of the works of Lefebvre and Leibniz on the differentiation between absolute and social space and the implications it can potentially hold for relationality, redress and reconciliation in South Africa.

\section{Law's spatial turn}

Space has always been with us and the study of spatiality has equally been on the agenda since the beginning of time (and space). The effects of space and the spatial on approaches and modes of thinking in different disciplines are also wellknown areas of inquiry by now. What is referred to as 'the spatial turn' therefore needs some clarification, since it is not necessarily a novel exercise. In fact it is rather out of date to suggest that the latest 'spatial turn', suggesting that the focus on space is a fresh occurrence, is truly new. However, there are still features that can be thought of as novel, or at least attributes that give the most recent emphasis on space a different hue. This can definitely be said of a deepened presence of space and spatial references in the writings of different humanities disciplines from 1960 onwards. Even though renewed attention to space generally speaking, in addition to emphasis on time, cannot be considered novel in the ordinary sense of the word, the turn is still new in law because spatiality as a critical idiom has not been widely accepted in legal theory or jurisprudence. Braverman et al. in the introduction of their edited collection The Expanding Spaces of Law identify three main waves in law's turn to spatiality: a cross-disciplinary wave, then an interdisciplinary wave and lastly a post-disciplinary wave (Braverman et al. 2014:2-12). Through their book they attempt to establish legal geography as a field of inquiry that is neither a subdiscipline of human geography nor a specialised area of law. They define legal geography as a stream of scholarship where the interconnectedness of law and spatiality (and in particular the ways in which the one constitutes the other) is the object of inquiry (2014:1). The cross-disciplinary explorations, with which the spatial turn can be said to have commenced, are linked to the Law and Society movement, started in the 1960s by Roscoe Pound. There were also human geographers who were concerned with legal issues, but notably not concerned with the law as such. During the 1980s, under this first wave, authors such as Gerald Neuman, John Calmore, Gerald Frug and Richard Briffault considered the spatial dimensions of community and its legal implications. In general this wave did not take account of the problematic, fluid and complex nature of space, apart from a few authors. One of these authors is Boaventura de Sousa Santos, whose 1987 'Law: a map of misreading toward a postmodern conception of law' introduced a new legal common sense. The second wave consisted of interdisciplinary scholars of spatiality. It was triggered by the Critical Legal Studies movement of the 1980s and 1990s. Underlying theoretical foundations included neo-Marxism and poststructuralism. Key works from this time included Gordon Clark's Judges and the Cities (1985), Nicholas Blomley's
Law, Space, and the Geographies of Power (1994) and David Delaney's Race, Place, and the Law, 1836-1948 (1998). Davina Cooper's Governing out of Order: Space, Law and the Politics of Belonging was an explicitly and normatively critical work that raised the question of policy-relevant research versus ethical perspectives. The work of Lisa Pruitt exposes what she terms the 'metronormative' urban bias. The third, or post-disciplinary, wave does not see law and spatiality as belonging to separate disciplines. The inquiry is therefore neither across nor between disciplines but rather beyond the mere concept of disciplines. It introduces as such a third field' (Braverman et al. 2014:9-12). This wave embraces legal pluralism, a view that does not view law as primarily and inherently the project of the state.

A central text in spatial justice is Butler's Henri Lefebore: Spatial Politics, Everyday Life and the Right to the City (2012). Lefebvre, whose work has mainly been engaged within geography, urban planning, cultural studies and social theory, is here examined in depth within the context of legal studies. Butler gives a thorough analysis of Lefebvre's work and its relevance in the fields of law and state power. His central argument is that critical legal scholars can rely on Lefebvre's work in order to formulate a view of the law as continuous processes of production - political struggles over inhabitance that continuously shape law and state power. I now turn to the work of Lefebvre and in particular the influence of Leibniz on his view of space.

\section{Leibniz and Lefebvre}

Central to Leibniz's view of space is the idea that nature brings about difference. He based this assertion on the fact that there are no trees or even leaves of trees that look exactly like another. With this he noted that identity and repetition have an incongruous relationship to divergence and variation. Nature produces trees (repetition), but nature also produces differences (trees are not identical). Lefebvre uses this argument of Leibniz's to call for this principle to also be recognised in spaces created through by humans; he showed how these spaces are just as varied as the landscapes produced by nature (Lefebvre 1991:397).

Western historians generally agree that Descartes ended the Aristotelian tradition regarding space. For Aristotle, space and time were but parts of other categories that aided the grouping and naming of sensory observations and evidence. The contemporary view of space (which, like many branches of the sciences and especially mathematics, became systematically removed from the roots it shared with metaphysics) was introduced by Descartes. After Descartes, space and time were either seen as simple pragmatic apparatuses for assembling sensory data or were seen as somehow elevated above the information provided by the senses of the body. His Cartesian logic ushered in a view of space as absolute. The philosophers who came after Descartes (Spinoza, Newtonians, Leibniz) considered space as such a dominant category that the questions they debated were whether space was a divine quality or an 'order immanent to 
the totality of what existed' (Lefebvre 1991:1). It was Kant who brought back the former idea of space as category. For Kant, space was relative, an ontological tool and a way to group together phenomena. However, it was removed from the empirical sphere and was seen as a subset of the foundation of consciousness. That entailed space participating in the internal and the ideal, and accordingly it took on qualities of the transcendental, which ultimately made it ungraspable (Lefebvre 1991:2).

Metaphysical thought (or classic philosophy) presented space as a substance in itself, which Lefebvre terms 'absolute space' (1991:169). He explained that Spinoza attributed space to an absolute being (for Spinoza this absolute being was God). Seen in this manner, space could be perceived as infinite and therefore without shape or content. Space thusly perceived; as without direction, form or orientation, could create the impression that it is not something that can be known or understood. Space as such could not be fathomed. However, Lefebvre instead insists on the formulation of Leibniz, namely that space, despite its divine and absolute attribution, is not unknowable but instead 'indiscernible'. The significance of viewing space as indiscernible as opposed to incomprehensible lies in Leibniz's understanding of 'indiscernible'. He proposes that space cannot be reduced to anything: 'Space in itself [is] neither "nothing" nor "something" - and even less the totality of things or the form of their sum' (Lefebvre 1991:169). Lefebvre emphasises that Leibniz's view is preferred by modern mathematics, even though philosophers have taken space and its proportions and figures for granted. To discern space or to discern something within space requires, for Leibniz, that there must be axes that have direction, that is, an axis must have an origin as well as a left and a right. Moreover, because space in itself is indiscernible, it needs to be occupied in order to be discerned. Furthermore, for Leibniz, it cannot merely be occupied by any body or any object; instead it should be a body that gives direction to space and can define and demarcate it (Lefebvre 1991:170). This brings Lefebvre to conclude that Leibnizian space is simultaneously concrete and abstract - abstract because it is underpinned by mathematical thinking that gives space a primordial and transcendental character and yet also concrete because it is marked by the requirement of occupation. The rejection of abstract space (space as an a priori vacuum with only formal attributes) entails the rejection of a certain representation of space. Lefebvre emphasises that Leibniz rejects abstract space and distances himself from the idea of space as an empty container that waits only to be filled with bodies. The logic of the container is ruled by separateness. In a container, separate, separated and separable entities collect in fragmented fashion. He argues that this mode of separation is transferred to entities and their components:

... fragmentation replaces thought, and thought, reflective thinking, becomes hazy and may eventually be swallowed up in the empirical activity of simply counting things. (Lefebvre 1991:170)
Lefebvre calls this the 'logic of separation' that supports and is constituted by a 'strategy of separation' (Lefebvre 1991:170). In light of this, Lefebvre proposes a different conjecture. He suggests that the only alternative that one can pose to the logic of separation that marks abstract space is to think whether a body can make space. He highlights in particular the body's ability to be active and the varying energies of bodies. Because there is a direct link between the body and the space of the body, there is a relationship between the body's 'occupation of' and 'deployment in' space (Lefebvre 1991:170):

Before producing effects in the material realm (tools and objects), before producing itself by drawing nourishment from that realm, and before reproducing itself by generating other bodies, each living body is space and has its space: it produces itself in space and it also produces that space. This is a truly remarkable relationship: the body with the energies at its disposal, the living body, creates or produces its own space; conversely, the laws of space, which is to say the laws of discrimination in space, also govern the living body and the deployment of its energies. (Lefebvre 1991:170)

The idea of space being produced by bodies and the relations between them is productive because it makes the concept of the reproduction of space possible, which correlates with notions of spatial memory or spatial legacy (Urban Development Framework 2014:10-11). In the next section I look at law's spatial turn in general. This discussion serves to shape an argument for reconciliation and for a spatial turn that acknowledges spatial production and opens up to the radical uncertainties of space.

\section{Leibniz and legal positivism}

Legal positivism, broadly speaking, is a school of law that views law as a precise science. Theorists attribute the start of positivism in Germany to Leibniz, who spent his life's work defending a fully codified legal system based on science. However, it was not only in codified systems of law that positivism was striven for but also in common law systems (of which South Africa is a good example). The aims of positivism, regardless of the area or jurisdiction, entail the creation of a coherent set of rules where law is acknowledged for what it is and where a complete rationalisation of law can be allowed.

Berkowitz investigates precisely these often unrecognised effects of the scientific foundations of modern law. His argument is that social scientific thinking presents a threat to justice. In his conceptualisation what social science does is to subject justice to notions of fairness, efficiency and legitimacy. Justice is replaced by these 'weaker' and more empirical and scientifically measureable notions (2005: ix-xvi). What takes place in this process is that the difference between justice and legitimacy becomes blurred where the force of the relation between positive law and democracy is asserted. Berkowitz convincingly shows how modern law has been transformed into a science, by providing an alternative genealogy of positive law. Where the ideal of justice is lost, Berkowitz 
says, law should reclaim its roots in the art of judgement rather than asserting its foundation in the science of law (2007:91). In the context of SPLUMA, this would mean a careful consideration of the various development principles: spatial justice, spatial efficiency, spatial resilience, spatial sustainability, and good administration. If the emphasis is placed on the empirical measureable notions of efficiency and sustainability, the danger is that justice will be lost in the process.

In jurisprudence, Leibniz is generally considered to be a natural law thinker and not a positivist. However, Berkowitz is interested in a reference to Leibniz in the introduction to an 1832 article by one of the leading positivists, John Austin. Because of this reference Berkowitz reconsiders the relation between Leibniz's work and the rise of legal positivism. He asks: 'What is an epigraph from the greatest natural lawyer of the 17th century doing on the title page of the work that has established itself as the locus classicus of 19th-century legal positivism?' (Berkowitz 2011:611). What connects Austin, the positivist, and Leibniz, the natural law thinker, is their shared commitment to using science to address the loss of law's 'natural, rational and traditional authority' and to employ science to respond to the rise of positive law (Berkowitz 2011:613). Berkowitz shows that the crisis of authority, which Nietzsche later called 'the death of God', led to a new form of law, namely law as a form of scientific reasoning. Law as science emerged as both the symptom and the cure for a crisis in authority. For Nietzsche, the death of God commenced with the attempt by Socrates to rescue a decomposing Greek civilisation by a new reliance on reason. However, Berkowitz argues that Socratic reasoning was simply another disease that further gnawed at the belief in truth that it was supposed to prove. This same pattern was followed in the social sciences that followed Leibniz's legal science, when they undermined all the grounds for legal authority. He states categorically that there has not been any science of law that could successfully establish itself as a true science of justice. Justice retreats in the face of legal science (Berkowitz 2011:627-628):

For some, the failure of science to refound law's authority has led to the recognition that science itself is interested, subjective, and suffused with political and metaphysical presuppositions. For others, the failure of legal science is an embarrassment. Most legal scholars, however, simply carry on as if the recourse to economic and democratic grounds for law were as natural as it is necessary. We all, to some degree, ignore the basic fact that the scientific cure for law has failed to restore law's once vibrant bond with justice. (Berkowitz 2011:629)

Linked to this possible danger of spatial justice to become just another cog in the machine of positivism, PhilippopoulosMihalopoulos problematises despatialised accounts of spatial justice. He is specifically critical of certain transdisciplinary modes of 'add space and stir' that risk insufficiently addressing the challenge of spatial justice because of a lack of theory (2015:182). He raises several specific problems with current discourses on spatial justice. One of them entails the failure of current spatial justice conversations to deal with the 'radical uncertainties' of space; they accordingly lose sight of the 'spatiality of space' (2015:183). PhilippopoulosMihalopoulos links this to a concern that spatial justice in its current epistemological form appears merely to be 'a battle for geography to assert the centrality of space', whilst it neglects the possibility of a 'transdisciplinary encounter between law and geography' (2015:183).

\section{Conclusion}

The spatial turn in the disciplines of the humanities can be traced to the 1960s and in law to around the 1980s. This renewed engagement with space and spatiality potentially presents a critical language with which the limits of the law can be interrogated. However, spatial discourse also, as per Philippopoulos-Mihalopoulos, offers the danger of merely re-establishing law's power and primacy. In this article, I drew attention to the importance of Leibniz's theory of the spatial turn in law, especially the way in which it has entered the legal discourse through the work of Lefebvre. Similar to Berkowitz's ambivalent description of Leibniz's work and his explanation of how Leibniz, usually considered a natural law thinker, has also been key to the development of legal positivism, I have observed a comparable hesitance regarding the spatial turn in law. Concepts such as the right to the city are increasingly interpreted within existing rights frameworks in order to translate this right into tangible human rights, which Lefebvre insists is not a human right as commonly understood but a cry and a demand that is intricately connected to the right to difference. Spatial language and the notion of spatiality cannot be merely metaphors employed in the service of strengthening law. If the spatial turn has anything to offer law, it is exactly the decentring and destabilising attributes of the discourse. The way in which spatiality is invoked and the role it plays in legal discourse will bring out the reconciliatory potential of spatial justice. A good current example of how spatial concepts such as belonging and the importance of place can be used for conservative means is captured by the Valhalla mosque scenario. A brief narration of this situation serves to conclude and illustrate the arguments raised above.

During the writing of this contribution, there was wide news coverage about the community of Valhalla in the city of Tshwane, which resisted the building of a mosque in a predominantly white neighbourhood (Pretorius 2016; Raborife 2016). The community's main claim was that there was insufficient consultation on this project and that the community was not invited to present their views on the erection of the mosque. ${ }^{1}$ In an interview the interviewer skilfully made it apparent that the demand for correct legal procedure (public consultation process) merely masked a deep underlying racist fear of the 'invasive nature of Islam'. The community spokesperson who was interviewed, Richard Botha, referred to the example of Laudium, where

1.The interview is available at http://www.news24.com/Live/SouthAfrica/News/sabcjournalist-challenges-valhalla-community-leader-over-mosque-20160419 (accessed 24 April 2016). 
people were 'forced out of the area' because of the 'expansionist way in which the Muslims take over'. Usually, before state land is alienated, notices go up and a process of public participation is put in place. This example of the mosque in Valhalla serves as a reminder in which the law can be used to entrench and reproduce racial stereotypes and spatial injustice. The formal processes of the law could, in this instance, be used to counter substantial attempts at redress and reconciliation.

The aim of this article was to provide a theoretical genealogy of the spatial turn in law and the concept of spatial justice. The main focus fell on the influence of the work of the mathematician, philosopher and lawyer Leibniz. Through the work of Berkowitz, I illustrated how Leibniz's view of space can also be co-opted by a legal positivist project, leading to the reproduction of unjust spaces and the continuation of spatial injustice. However, if the aims of SPLUMA to bring about spatial justice entail a genuine concern with space as relational and focus on justice as opposed to efficiency and resilience, the possibility arises of reconciliation through redress processes grounded in law.

\section{Acknowledgements Competing interests}

The author declares that she has no financial or personal relationships that may have inappropriately influenced her in writing this article.

\section{References}

Berkowitz, R., 2005, The gift of science: Leibniz and the modern legal tradition, Harvard University Press, Cambridge.

Berkowitz, R., 2007, 'Democratic legitimacy and the scientific foundation of modern law', Theoretical Inquiries in Law 8, 91-115.

Berkowitz, R., 2011, 'From justice to justification: An alternative genealogy of positive law', UC Irvine Law Review 1(3), 611-630.

Braverman, I., Blomley, N., Delaney, D. \& Kedar, A. (eds.), 2014, The expanding spaces of law: A timely legal geography, Stanford University Press, Stanford, CA.

Butler, C., 2012, Henri Lefebvre. Spatial politics, everyday life and the right to the city, Routledge, Oxon.

Integrated Urban Development Framework, 2014, viewed 22 September 2016, from http://www.cogta.gov.za/cgta_2016/wp-content/uploads/2016/05/FINALDRAFT-01-OCTOBER-2014-IUDF.pdf

Kesselring, R., 2016, Bodies of truth: Law, memory, and emancipation in postapartheid South Africa, Stanford Studies in Human Rights, Stanford, CA.

Lefebvre, H., 1991, Production of space, transl. D. Nicholson-Smith, Blackwell Publishing, Oxford.

Leibniz, G., 1714, Monadology, transl. R. Latta, 2014, ebooks@Adelaide, viewed 23 April 2016, from https://ebooks.adelaide.edu.au/l/leibniz/gottfried/1525m/

Massey, D., 1994, Space, place and gender, Polity Press, Cambridge.

Massey, D., 2005, For space, Sage, London.

Norval, A.J., 2009, “"No reconciliation without redress”: Articulating political demands in post-transitional South Africa', Critical Discourse Studies 6, 311-321. http:// dx.doi.org/10.1080/17405900903181176

Philippopoulos-Mihalopoulos, A., 2015, Spatial justice: Body, lawscape, atmosphere, Routledge, Oxon.

Pretorius, W., 2016, 'Valhalla mosque Islamophobia claim referred to CRL Commission', News24, 5 May, viewed 12 May 2016, from http://www.news24. com/SouthAfrica/News/valhalla-mosque-islamophobia-claim-referred-to-crlcommission-20160511

Raborife, M., 2016, 'Valhalla mosque protests pure racism - Tshwane Islamic trust' News24, 21 April, viewed 12 May 2016, from http://www.news24.com/ SouthAfrica/News/valhalla-mosque-protests-pure-racism-tshwane-islamictrust-20160421

Spatial Planning and Land Use Management Act 16 of 2013.

Tally, R., 2013, Spatiality: The new critical idiom, Routledge, Oxon. 